\title{
Relation of Dipicolinic Acid to Heat Resistance of Bacterial Spores
}

\author{
By N. GRECZ AND T. TANG \\ Biophysics Laboratory, Biology Department, \\ Illinois Institute of Technology, Chicago, Illinois 606I6, U.S.A. \\ (Accepted for publication 19 August 1970)
}

S UMMAR Y

\begin{abstract}
Spores of five strains of Clostridium botulinum differing widely in their heat resistance contained 7.4 to $13.4 \%$ dipicolinic acid. There appeared to be no correlation between DPA content and heat resistance of the various strains. The rate of loss of DPA during heating at 75 and $100^{\circ}$ was consistently slower than the rate of loss of spore viability, though, in general, heat-resistant strains lost DPA less quickly than did heat-sensitive strains. At the instant of thermal death, spores still retained 28 to $99.6 \%$ of their original DPA, though this DPA could be released on continued heating.
\end{abstract}

\section{INTRODUCTION}

Since its discovery by Powell (1953), dipicolinic acid (DPA, pyridine-2,6-dicarboxylic acid) has in various ways been related to heat resistance of bacterial spores. Spores as a group are exceptional in the biological world in that they contain large amounts of DPA: 5 to $15 \%$ of their dry weight (Church \& Halvorson, 1959; Murrell \& Warth, 1965; Murrell, Ohye \& Gordon, 1969). Appearance of heat resistance during formation and maturation of spores has been correlated with the synthesis of DPA (Perry \& Foster, 1955; Collier \& Murty, 1957; Hashimoto, Black \& Gerhardt, I960; Wooley \& Collier, I965).

Release of DPA from spores proceeds at a slower rate than loss of viability of spores during heating (Foster, I959; El-Bisi, Lechowich, Amaha \& Ordal, I962), or loss of heat resistance during spore germination (Wooley \& Collier, 1965). However, reports of a quantitative relationship between the spore's content of DPA and its degree of heat resistance are the subject of some controversy (Lund, I958; Lechowich \& Ordal, 1960; Levinson, Hyatt \& Moore, 196I; Byrne, Burton \& Koch, 1960; Walker, Matches \& Ayres, I96I; Murrell \& Warth, 1965; Murrell et al. 1969).

We have postulated that a relationship between the heat resistance of a bacterial spore and the rate at which its DPA is released on heating would be a reasonable probability in that it would relate the heat resistance to the energy required to remove DPA from any hypothetical protective spore-DPA complex(es) such as have been postulated by various workers (Halvorson, 1958; Riemann, 1963; Tang, Rajan \& Grecz, I968). In order to test this hypothesis, it was desirable to select a taxonomically closely related group of bacteria whose spores demonstrated widely different resistances to heat; Clostridium botulinum was selected since the heat resistance of the spores of different strains of this species vary by as much as 1000-fold (Murrell, 1955). 


\section{METHODS}

Test organisms. The five strains of three serological types (A, B, E) of Clostridium botulinum in Table I were used.

Spore production. The sporulation medium consisted of $5 \%$ trypticase (BBL) and $0.5 \%$ peptone (Difco) to which freshly sterilized I0 $\%(\mathrm{w} / \mathrm{v})$ sodium thioglycollate was added to $0.1 \%$ just before inoculation. For production of spores of type E, freshly sterilized $10 \%$ glucose was added aseptically to $\mathrm{I} \%$.

Table I. Strains of Clostridium botulinum

\begin{tabular}{|c|c|c|c|}
\hline $\begin{array}{l}\text { Strain } \\
\text { no. }\end{array}$ & $\begin{array}{l}\text { Serological } \\
\text { type }\end{array}$ & $\begin{array}{l}\text { Heat } \\
\text { resistance }\end{array}$ & $\begin{array}{l}\text { Source of } \\
\text { culture }\end{array}$ \\
\hline V.H.* & $\mathrm{E}$ & Very low & $\begin{array}{l}\text { Food Research Institute, University of } \\
\text { Chicago }\end{array}$ \\
\hline 5 I B & B & Low & $\begin{array}{l}\text { K. F. Meyer, University of California } \\
\text { (isolated from toxic cheese) }\end{array}$ \\
\hline $\begin{array}{l}41 \mathrm{~B} \\
36 \mathrm{~A} \\
33 \mathrm{~A}\end{array}$ & $\begin{array}{l}\text { B } \\
\mathrm{A} \\
\mathrm{A}\end{array}$ & $\left.\begin{array}{l}\text { Very high } \\
\text { Low } \\
\text { High }\end{array}\right\}$ & $\begin{array}{l}\text { W. E. Perkins, National Canners } \\
\text { Association, Berkeley, California }\end{array}$ \\
\hline
\end{tabular}

The inoculum was built up by incubating $20 \mathrm{ml}$. of medium in a screw-cap tube with $2 \mathrm{ml}$. of the stock culture. To activate the spores for germination they were heatshocked at $80^{\circ}$ for $10 \mathrm{~min}$. (type $\mathrm{A}$ and type B strains), or $60^{\circ}$ for $\mathrm{I} 3 \mathrm{~min}$. (type $\mathrm{E}$ strain). Serial transfers were carried out at daily intervals for 2 to 3 days to obtain an actively growing culture. Aliquots of $10 \mathrm{ml}$. of this culture were inoculated into $5 \mathrm{oz}$. prescription bottles each of which contained $100 \mathrm{ml}$. of freshly prepared sporulation medium. The bottles were inverted several times in a 9 and $\mathrm{I} 7 \mathrm{~h}$. cycle. Incubation was carried out at $30^{\circ}$ and the progress of sporulation was followed by phase contrast microscopy. Spores were harvested by continuous centrifugation in a refrigerated Servall RC-2 centrifuge, washed three times in distilled water, resuspended in $0.067 \mathrm{M}$ Sorenson's phosphate buffer $(\mathrm{pH} 7)$ and stored at $-20^{\circ}$ until needed.

Heat treatment. Heating was carried out in a 'Hot-Pack' water bath. To eliminate corrections for the time necessary to reach the heating temperature, the suspending buffer was first heated to the desired temperature. The stock spore suspension was added at zero time to give $10^{7}$ to $10^{8}$ spores $/ \mathrm{ml}$.; samples were withdrawn at intervals, rapidly cooled in ice and stored in the refrigerator. Spore viability was determined by colony counts in oval culture tubes using the medium of Wynne, Schmieding \& Daye (I955) solidified with I.5\% agar.

DPA was assayed by $(a)$ the colorimetric method of Janssen, Lund \& Anderson (1958) or $(b)$ the direct spectrophotometric determination of the extinction at $270 \mathrm{~nm}$. of the ethyl ether fraction obtained by reflux extraction (Perry \& Foster, 1955).

RESULTS

\section{Release of DPA during heating}

Fig. I compares the rate of loss of DPA during thermal inactivation at $75^{\circ}$ of spores of Clostridium botulinum strain 33A (type A, heat resistant) $v$. strain vH (type E, heat 
sensitive). Strain 33A exhibited a relatively slow decline of the number of viable spores; the time necessary to destroy $90 \%$ of the spores $\left(D_{75}\right)$ was approximately I 50 min. Release of DPA from strain $33 \mathrm{~A}$ at $75^{\circ}$ was barely measurable.

Strain VH.E showed a rather rapid rate of death within the first 10 min. followed by a less pronounced death rate on longer heating. The $D_{75}$ for the initial portion of the survival curve was approximately $9 \mathrm{~min}$. The rate of loss of DPA during the first Io min. was relatively rapid, i.e. only slightly slower than the rate of loss of viable spores. Furthermore, on heating beyond 10 min. the rate of loss of DPA appeared to exceed the rate of loss of spore viability.

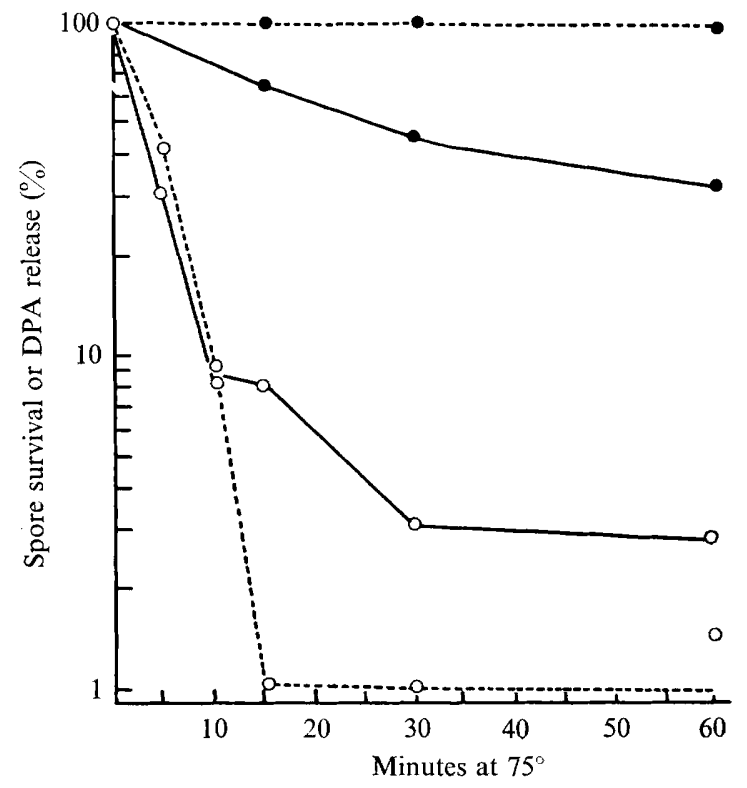

Fig. I. Relation between thermal loss of dipicolinic acid and loss of viability of spores of Clostridium botulinum. The solid lines represent spore survival and the broken lines DPA release; 9 , strain $33 \mathrm{~A}$; O, strain VH.E.

Fig. 2 shows that during heating at $100^{\circ}$ the initial rate of loss of DPA from four strains of Clostridium botulinum was consistently slower than the rate of loss of spore viability. Delay in DPA release such as observed here in C. botulinum has been repeatedly reported in studies with spores of other micro-organisms (Lund, 1958; Foster, 1959; El-Bisi et al. 1962).

Apparent exceptions were strains VH.E (Fig. I) and 36 A (Fig. 2), which exhibited a rate of release of DPA which after Io min. of heating seemed to exceed the rate of loss of spore viability. However, unlike the other organisms studied, these two strains had distinctly diphasic survival curves suggesting that their spore populations were heterogeneous. The survival curves indicated that the populations consisted of approximately 90 to $98 \%$ heat-sensitive spores responsible for the steep initial decline, and 2 to $10 \%$ of heat-resistant spores responsible for the characteristic change in slope of the survival curves after 5 to $10 \mathrm{~min}$. of heating. The small number of heat-resistant spores in the residual population would not contribute any measureable amount of 
DPA. Under these conditions, one would expect to obtain the results found with strains VH.E and 36 A. Similar diphasic survival curves have been reported by Graikoski \& Kempe (1964) and Roberts \& Ingram (1965) for spores of Clostridium botulinum type $\mathrm{E}$.

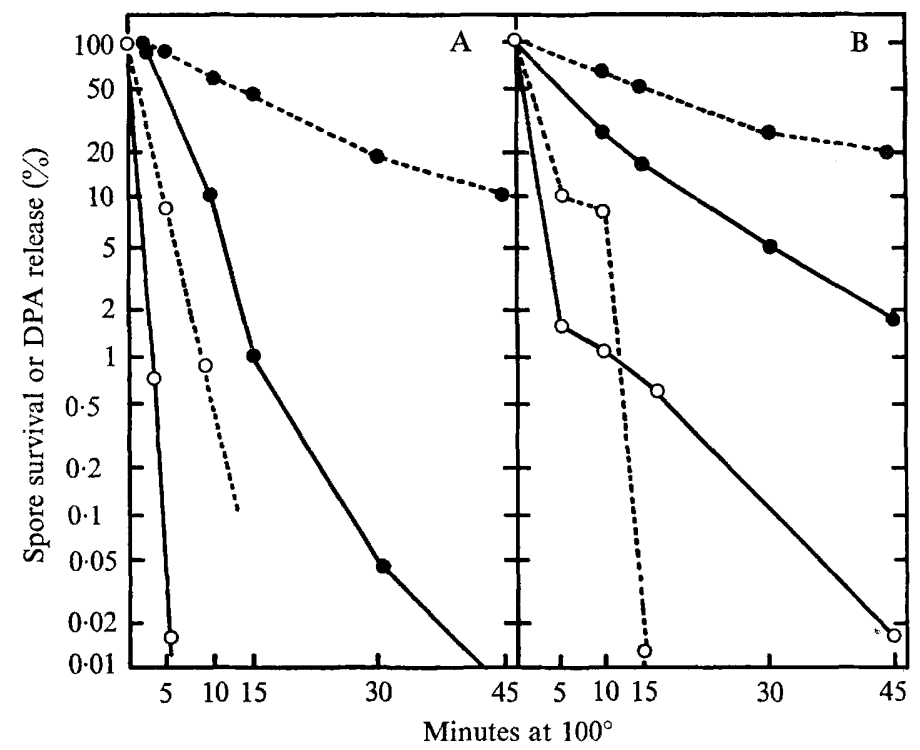

Fig. 2. Relation between thermal loss of dipicolinic acid and loss of viability of spores of Clostridium botulinum. The solid lines represent spore survival and the broken lines DPA release. A: O, strain 33A; O, strain 5I B. B: 0 , strain 4I B; O, strain $36 \mathrm{~A}$.

Table 2. Release of DPA from spores of Clostridium botulinum strains of differing heat resistance

\begin{tabular}{|c|c|c|c|c|c|}
\hline \multirow[b]{2}{*}{ Strains* } & \multirow{2}{*}{$\begin{array}{l}\text { Total DPA } \\
\text { (\% dry wt) }\end{array}$} & \multicolumn{2}{|c|}{$D$ (spore viability) $\dagger$} & \multicolumn{2}{|c|}{$D$ (loss of DPA $) \ddagger$} \\
\hline & & $75^{\circ}$ & $100^{\circ}$ & $75^{\circ}$ & $100^{\circ}$ \\
\hline & & $\min$. & $\min$. & $\min$ & min. \\
\hline $33 \mathrm{~A}$ & I3.4 & 150 & Io & $>23 \mathrm{~h}$. & 42 \\
\hline $36 \mathrm{~A}$ & $8 \cdot 7$ & - & $3 \cdot 0 ; 20$ & - & 5 \\
\hline $4 \mathrm{IB}$ & $8 \cdot 1$ & - & 27 & - & $>50$ \\
\hline $5 \mathrm{IB}$ & $7 \cdot 4$ & - & 2.5 & - & 4 \\
\hline VH.E & 9.5 & $9 \cdot 0$ & - & Io $\mathrm{min}$ & - \\
\hline
\end{tabular}

* The letters A, B, and E signify serological types.

$\dagger D$ (spore viability) $=$ the decimal reduction time, i.e. the time required for a $90 \%$ decrease in viable spores at the specified temperature.

$+D$ (loss of DPA $)=$ the time required for a $90 \%$ loss of DPA at the specified temperature.

There was no detectable correlation between the DPA-content of spores and their heat resistance (Table I). Thus the most sensitive strain (VH.E) and the most resistant strain (4I B) both contained about the same amount of DPA, namely 9.5 and $8 \cdot 1 \%$ respectively.

However, there seemed to be some correlation between the rate of loss of spore viability (i.e. heat resistance) and the rate of loss of DPA. From Fig. I and 2 it was 
estimated that the heat-sensitive strains $36 \mathrm{~A}$ and $5 \mathrm{I} \mathrm{B}$ lost $90 \%$ of their DPA within 4 to 5 min. at $100^{\circ}$, whereas the heat-resistant strains $33 \mathrm{~A}$ and $4 \mathrm{I} \mathrm{B}$ lost $90 \%$ of their DPA within 42 and $>50$ min. respectively.

From the $D$ values listed in Table 2, the ratio of the rate of loss of DPA to the rate of loss of viability at $100^{\circ}$ was $I \cdot 6$ to $I \cdot 7$ for the heat-sensitive strains and 2 to 4 for the heat-resistant strains. These ratios represent the extent by which loss of DPA lagged behind loss of viability. In this sense it may be concluded that in general the more heat-resistant strains retained DPA during heating more tenaciously than did the less heat-resistant strains.

\section{Retention of DPA by heat-killed spores}

To determine whether there was any correspondence between the amount of DPA which remained spore-bound after various periods of heating and the number of spores that survived this treatment to retain their viability, the total residual spore-bound DPA was assayed and expressed as a $\%(w / w)$ of the calculated dry weight of the

Table 3. Effects of $(a)$ viability and $(b)$ DPA retention of heating spores of Clostridium botulinum $33 \mathrm{~A}$ at $100^{\circ}$

The amounts of DPA retained has been calculated as a percentage of the dry weight of the surviving, viable spores.

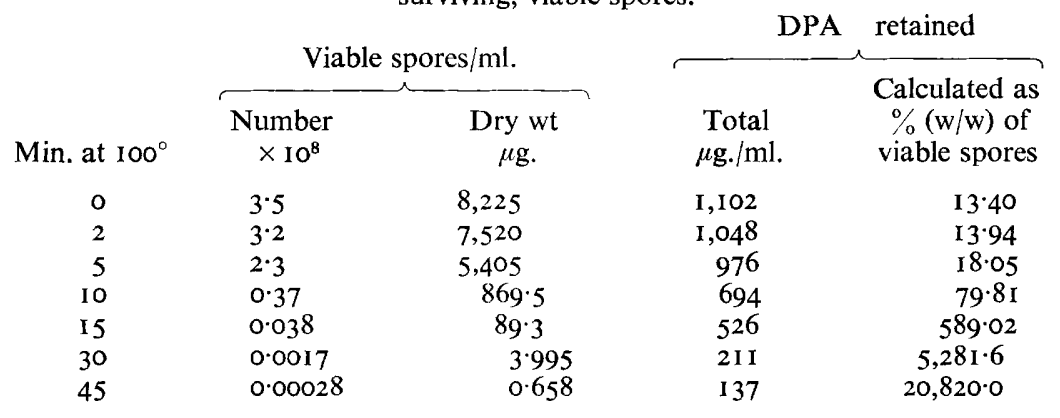

surviving, viable spores. This experimentally determined ratio was then compared with the known DPA content of unheated, viable spores of this species (I $3.4 \%, w / w)$. Three possibilities were envisaged: that this experimental ratio would possess (i) a value of $13.4 \%$, which would mean that heat-killed spores must be devoid of DPA; or (ii) a value of $<\mathrm{I} 3.4 \%$, which would indicate total or very extensive loss of DPA from killed spores plus some loss of DPA from surviving, viable spores; or (iii) a value of $>13.4 \%$, in which case some DPA must have been retained by heat-killed spores irrespective of whether some DPA might simultaneously have been lost by surviving, viable spores.

Table 3 (last column) shows that possibility (iii) was in fact the actual situation. The calculated ratio steadily increased above the initial $13.4 \%$, reaching over $20,000 \%$ after $45 \mathrm{~min}$. of heating. Apparently, a considerable amount of DPA was retained by heat-killed spores. Thus it may be concluded that the thermal resistance of the spore was broken some time before all its DPA was lost.

The amount of DPA which may be retained in the spore at the instant of its death was estimated by plotting the number of spores killed $v$. amount of DPA released, 
expressed as a percentage of the dry weight of killed spores (Fig. 3). During the initial heating, rapid loss of spore viability occurred with relatively little loss of DPA; this is evident from the steeply ascending portions of the plots in Fig. 3. On more prolonged heating, following the death of most of the spore population, additional DPA continued to be released as shown by the horizontal plateau of the plots in Fig. 3. The sharp 'breaking point' at the intersection of the horizontal and ascending portions of a plot represents the point of maximal destruction of spore viability, namely at this point the spore population was inactivated to the extent of 94 to $98 \%$ (at $100^{\circ}$ ) and 9I to $92 \%$ (at $75^{\circ}$ ). At the 'breaking point' the amount of DPA which had been

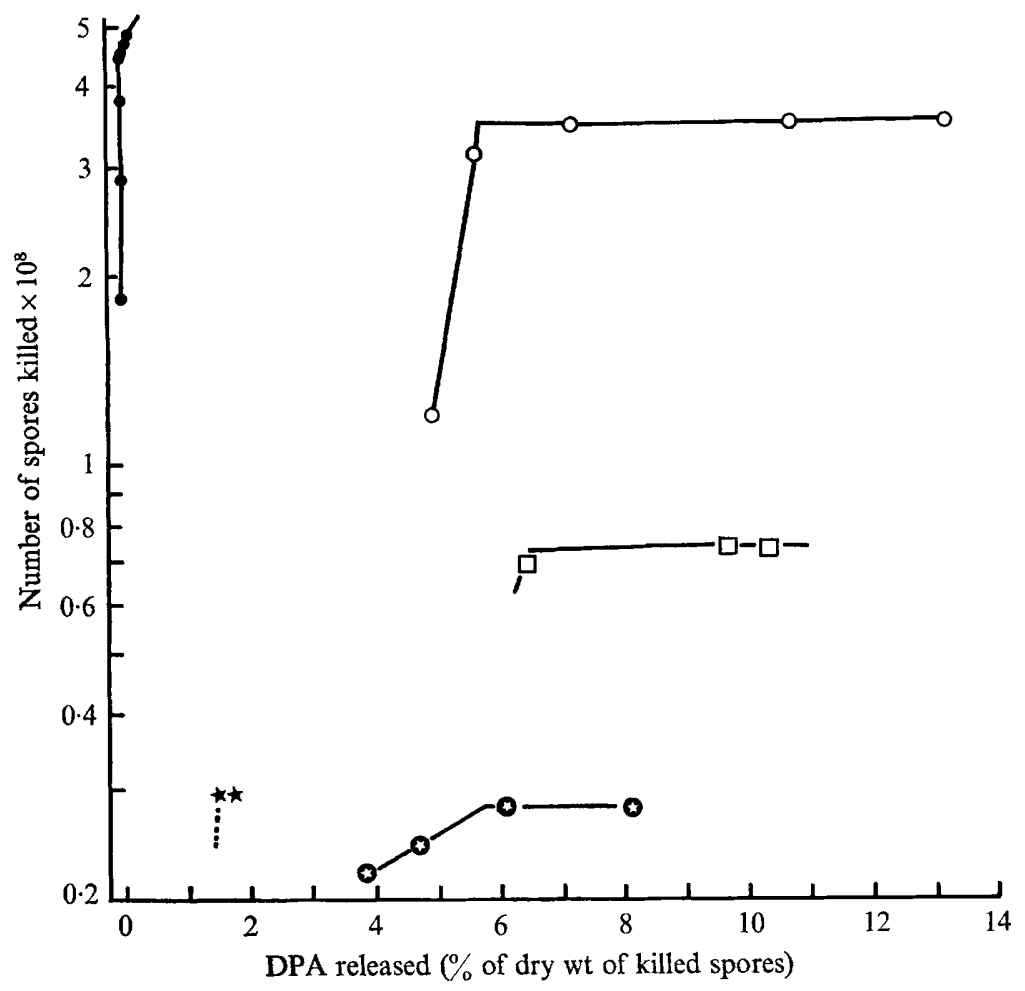

Fig. 3. Relation of released DPA to the number of spores killed during heating. The strain numbers and the temperature at which the spores were heated are as follows: $\bullet, 33 \mathrm{~A}$, $75^{\circ} ; \mathrm{O}, 33 \mathrm{~A}, 100^{\circ} ; \square, \mathrm{VH} . \mathrm{E}, 75^{\circ} ; \star, 36 \mathrm{~A}, 100^{\circ}$; and $\boldsymbol{\oplus}, 41 \mathrm{~B}, 100^{\circ}$.

Table 4. Consequences of heating spores of Clostridium botulinum strains to the 'breaking points' indicated in Fig. 3

\begin{tabular}{|c|c|c|c|c|c|}
\hline \multirow[b]{2}{*}{ Strain } & \multirow{2}{*}{$\begin{array}{l}\text { Heating } \\
\text { temp. } \\
\left({ }^{\circ} \mathrm{C}\right)\end{array}$} & \multirow{2}{*}{$\begin{array}{c}\text { Spores } \\
\text { killed } \\
\text { (\% of total) }\end{array}$} & \multicolumn{2}{|c|}{$\%$ By wt of spore } & \multirow{2}{*}{$\begin{array}{l}\% \text { of initial } \\
\text { content } \\
\text { retained }\end{array}$} \\
\hline & & & Lost & Retained & \\
\hline $33 \mathrm{~A}$ & 100 & 97 & 5.8 & $7 \cdot 6$ & 57 \\
\hline $4 \mathrm{IB}$ & 100 & 94 & $5 \cdot 8$ & $3 \cdot 2$ & 28 \\
\hline $36 \mathrm{~A}$ & 100 & 98 & I. 56 & $7 \cdot 14$ & 83 \\
\hline $33 \mathrm{~A}$ & 75 & $9 \mathrm{I}$ & 0.05 & 13.35 & $99 \cdot 6$ \\
\hline VH.E & 75 & 92 & $6 \cdot 44$ & 3.06 & 32 \\
\hline
\end{tabular}


released from the spores was strain-determined and varied over a range from 0.4 to $72 \%$ of the total initial DPA concentration (Table 4 ); therefore, at the instant of thermal death, all spores must have retained a considerable amount of their DPA, conceivably as much as 28 to $99 \cdot 6 \%$.

\section{DISCUSSION}

Our experiments have established a correlation between the rate of DPA loss during heating and the rate of thermal death of spores. However, the evidence does not enable one to say whether the loss of DPA is intimately connected with the event of thermal death or is merely a consequence of general structural degradation within the spore.

Release of DPA from spores during heating may involve at least two distinct sequential steps: (i) breaking or detachment of hypothetical DPA complexes from attachment sites in the spore (Rieman, 1963; Tang et al. 1968); and (ii) leakage of DPA or DPA complex(es) through the spore membranes and coats.

If DPA plays a role in heat resistance, step (i) may lead to denaturation of vital biopolymers and death of the spore even though DPA may remain trapped or adsorbed in the spore; only step (ii) would result in measurable loss of DPA into the medium.

In our strain 33 A (Fig. I), DPA may have been permanently or transiently released from its binding sites at $75^{\circ}$, resulting in extensive spore inactivation. However, the permeability of spore membranes and coats may not have been sufficiently affected to allow extensive loss of DPA to occur. At the same temperature the membranes or coats of the heat-sensitive strain VH type E may have been disorganized to such a degree that DPA penetrated them freely and was rapidly lost.

The relationship between a spore's content of DPA and its heat resistance, although widely believed, has never been satisfactorily proved. Furthermore, in addition to DPA, other mechanisms have been postulated, e.g. stabilizing -S-S- cross-linking predominant in spore protein (Vinter, 1961), gel-like spore interior analogous to thiolated gelatins (Black \& Gerhardt, I962), or stabilization by peptidoglycan polymer network of the spore cortex (Murrell et al. 1969). The existence of several parallel mechanisms would explain why spores of DPA-less mutants (Halvorson \& Swanson, 1969), although much less heat-resistant than those of the wild type, are still more heat-resistant than vegetative cells.

Because of the many possible factors which may play a role in the thermal inactivation of spores and which may differ from strain to strain, one would not expect there to exist a simple relationship between heat resistance and either the amount of DPA or the rate of release of DPA during heating.

This work was supported by U.S. Public Health Service Grant UI oor 38 and PHS Career Development Award 5-K3-AI-2 I,763. We thank Dr H. O. Halvorson, Dr. G. Gould, Dr W. G. Murrell and Dr R. Slepecky for their critical review of the manuscript.

\section{REFERENCES}

Black, S. H. \& Gerhardt, P. (1962). Permeability of bacterial spores. IV. Water content, uptake, and distribution. Journal. of Bacteriology 83, 960-967.

Byrne, A. F., Burton, H. T. \& Koch, R. B. (1960). Relation of dipicolinic acid content of anaerobic bacterial endospores to their heat resistance. Journal of Bacteriology 80, I39-140. 
Church, B. D. \& Halvorson, H. (1959). Dependence of the heat resistance of bacterial endospores on their dipicolinic acid content. Nature, London 183, I24-I 25.

Collier, R. E. \& MURTY, G. G. K. (1957). The correlation of dipicolinic acid synthesis with the sporulation of Clostridium roseum. Bacteriological Proceedings p. 32.

El-Bisi, H. M., Lechowich, R. V., Amaha, M. \& Ordal, Z. J. (I962). Chemical events during death of bacterial endospores by moist heat. Journal of Food Science 27, 219-231.

Foster, J. W. (1959). Dipicolinic Acid and Bacterial Spores. Booklet containing text of lecture presented on 22 October 1959 at the University of Maryland, College Park, Maryland.

Graikoski, J. T. \& KEMPE, L. L. (1964). Heat resistance of Clostridium botulinum type E spores. Bacteriological Proceedings p. 3.

Halvorson, H. O. (1958). The Physiology of Bacterial Spores. Technical University of Norway, Trondheim.

Halvorson, H. O. \& Swanson, A. (1969). Role of dipicolinic acid in the physiology of bacterial spores. In Spores, vol. IV, pp. I2I-I 32. Edited by L. L. Campbell. Bethesda: American Society for Microbiology.

Hashimoto, T., Black, S. H. \& Gerhardt, P. (I960). Development of fine structure, thermostability and dipicolinate during sporogenesis in a Bacillus. Canadian Journal of Microbiology 6, 203-213.

Janssen, F. W., LUND, A. J. \& ANDerson, L. E. (1958). Colorimetric assay for dipicolinic acid in bacterial spores. Science, New York 127, 26-27.

LECHOWICH, R. V. \& ORDAL, Z. J. (1960). The influence of sporulation temperature on the thermal resistance and chemical composition of endospores. Bacteriological Proceedings, pp. 44-45.

Levison, H. S., HyatT, M. T. \& Moore, F. E. (I96I). Dependence of the heat resistance of bacterial spores on the calcium:dipicolinic acid ratio. Biochemical and Biophysical Research Communications 5, 417-421.

LUND, A. (1958). In Annual Report of the Hormel Institute, 1957/58.

Murrell, W. G. (1955). The Bacterial Endospore. Monograph published by the University of Sydney, Australia.

Murrell, W. G. \& Warth, A. D. (1965). Composition and heat resistance of bacterial spores. In Spores, vol. III, pp. I-24. Edited by L. L. Campbell \& H. O. Halvorson. Ann Arbor, Michigan: American Society for Microbiology.

Murrell, W. G., OhYe, D. F. \& Gordon, R. A. (1969). Cytological and chemical structure of the spore. In Spores, vol. Iv, pp. I-I9. Edited by L. L. Campbell. Bethesda: American Society for Microbiology.

Perry, J. J. \& Foster, J. W. (1955). Studies on the biosynthesis of dipicolinic acid in spores of Bacillus cereus var. mycoides. Journal of Bacteriology 69, 337-346.

PowelL, J. F. (1953). Isolation of dipicolinic acid (pyridine-2,6-dicarboxylic acid) from spores of Bacillus megatherium. Biochemical Journal 54, 2 10-2 II.

RiemanN, H. (1963). Germination of Bacterial Spores with Chelators. Copenhagen: Th. Bang.

ROBERTS, T. A. \& INGRAm, M. (I965). The resistance of spores of Clostridium botulinum type E to heat and radiation. Journal of Applied Bacteriology 28, $125-138$.

TANG, T., RAJAN, K. S. \& GRECZ, N. (I968). Mixed chelates of Ca(II)-pyridine-2,6-dicarboxylate with some amino acids related to bacterial spores. Biophysical Journal 8, I458-1474.

VINTER, V. (196I). The formation of cystine-rich structure in sporulating cells and its possible role in the resistance of spores. In Spores, vol. II, pp. I27-I4I. Edited by H. O. Halvorson. Minneapolis, Minnesota: Burgess Publishing Company.

Walker, H. W., Matches, J. R. \& Ayres, J. C. (1961). Chemical composition and heat resistance of some aerobic bacterial spores. Journal of Bacteriology 82, 960-966.

Wooley, B. C. \& Collier, R. E. (1965). Changes in thermoresistance of Clostridium roseum as related to the intracellular content of calcium and dipicolinic acid. Canadian Journal of Microbiology 11, 279-285.

Wynne, E. S., Schmieding, W. R. \& Daye, G. T., Jun. (1955). A simplified medium for counting Clostridium spores. Food Research 20, 9-12. 